\title{
PEMBENTUKAN TARGET PASAR BERDASARKAN DATA STREAM TRANSAKSI KARTU KREDIT (CLUSTERING DAN ASSOCIATION RULE) PADA PT BANK BUKOPIN
}

\author{
ESTABLISHMENT OF TARGET MARKET BASED ON THE DATA STREAM OF CREDIT CARD \\ TRANSACTIONS (CLUSTERING AND ASSOCIATION RULE) AT PT BANK BUKOPIN
}

\author{
Muhammad Riza")1, Kudang Boro Seminar ${ }^{* *}$, dan Agus Maulana ${ }^{* * *}$ \\ *) Sekolah Bisnis, Institut Pertanian Bogor \\ Jl. Raya Pajajaran, Bogor 16151 \\ **) Departemen Teknik Mesin dan Biosistem, Fakultas Teknologi Pertanian, Institut Pertanian Bogor \\ Kampus IPB Darmaga, Jl. Lingkar Akademik, Jawa Barat 16680 \\ $\left.{ }^{* * *}\right)$ Universitas Dr Sutomo \\ Jl. Semolowaru No.84, Surabaya 60118
}

\begin{abstract}
The purpose of research is to analyze the formation of the target market customer segmentation based on job characteristics, income, education, age, region of origin, and patterns of credit card merchant. The data were analyzed using two data mining techniques of clustering with K-Means and Association Rule Mining (ARM) and supported by Apriori and Random Sampling technique with the Slovin formula and Principal Component Analysis (PCA). The clustering tests in 10 replications on the sampling of 350 clients supported by PCA produced the three best clusters that had the silhouette value close to 1 i.e. 0.39 to 0.40. Meanwhile, the ARM Testing with Apriori using a minimum support of 1\% and a minimum confidence of $40 \%$ produced two patterns of credit card merchant transactions. In the first pattern, when the Hotel merchant type (hhl) was transacted, the Restaurant merchant type (RRT) was also transacted, and in the second pattern, if the Service Station merchant type (RSS) was transacted, the Restaurant merchant type (RRT) was also transacted. The three clusters and two types of merchant patterns obtained can generate inputs for the company to identify its potential customers based on the characteristics of the target customers by connecting them to the merchant type pattern frequently used.
\end{abstract}

Keywords: credit card, data mining, clustering, ARM, data stream

\begin{abstract}
Abstrak: Tujuan penelitian adalah untuk menganalisis pembentukan target pasar segmentasi nasabah dengan karakteristik pekerjaan, penghasilan, pendidikan, usia, asal wilayah dan pola merchant kartu kredit. Teknik analisis data menggunakan dua teknik data mining, yaitu clustering dengan K-Means dan Association Rule Mining (ARM) dengan Apriori didukung juga dengan teknik Random Sampling dengan rumus Slovin serta Principal Component Analysis (PCA). Hasil pengujian clustering 10 kali percobaan pada sampling 350 nasabah dengan dukungan PCA menghasilkan tiga buah cluster terbaik yang memiliki nilai silhouette mendekati 1 sebesar 0,39-0,40. Sementara hasil pengujian ARM dengan Apriori menggunakan minimum support 1\% dan minimum confidence $40 \%$ menghasilkan dua buah pola transaksi merchant kartu kredit, yaitu pola pertama merchant jenis Hotel (HHL) ditransaksikan maka merchant jenis Restaurant (RRT) ikut ditransaksikan dan pola kedua jika merchant jenis Service Station (RSS) ditransaksikan maka merchant jenis Restaurant (RRT) akan ikut ditransaksikan. Tiga cluster dan dua pola jenis merchant yang terbentuk menghasilkan masukan bagi perusahaan untuk mengidentifikasi target nasabah potensial berdasarkan karakteristik nasabah dengan menghubungkannya pada pola jenis merchant yang sering ditransaksikan.
\end{abstract}

Kata kunci: kartu kredit, data mining, klasterisasi, ARM, data stream

\footnotetext{
${ }^{1}$ Corresponding author:

Email: mriss.cold@gmail.com
} 


\section{PENDAHULUAN}

Bidang pemasaran memegang peranan yang cukup vital dalam setiap usaha bisnis. Pengembangan pemasaran dalam mencapai tujuan bisnis seperti: bertahan hidup, memperoleh keuntungan dan berkembang (Kotler dan Armstrong, 2008) merupakan bagian terpenting dalam pengembangan bisnis perusahaan. Memahami bagaimana konsumen menanggapi tawaran perusahaan, memilih dan memutuskan produk (Bayer, 2010) yang digunakan merupakan kunci sukses dalam mencapai tujuan perusahaan. Oleh karena itu, perlu memahami bagaimana segmentasi dan pola bertransaksi konsumen agar menjadi bahan pertimbangan manajemen perusahaan dalam merencanakan strategi pemasaran (Mabrur dan Lubis, 2012).

Produk bisnis kartu kredit pada perbankan merupakan salah satu bidang usaha bisnis konsumer atau ritel yang terus mengalami pertumbuhan data. Kartu kredit memiliki peranan besar bagi perseroan sebagai produk yang memberikan kemudahan dalam bertransaksi dan menjadi perhatian besar dalam pertumbuhan perusahaan. Bank Bukopin mulai meluncurkan kartu kredit sejak tahun 2009 terdiri atas Visa dan Master Card. Di tahun 2014 realisasi kinerja bisnis produk konsumer kartu kredit meningkat lebih besar dari produk lainnya sebesar $41,8 \%$ dan telah memberikan kontribusi besar pada fee based income perusahaan. Peningkatan kinerja bisnis produk consumer pada pertumbuhan jumlah pemegang kartu tidak diimbangi dengan meningkatnya pertumbuhan transaksi dari 5,6 kali rata-rata jumlah transaksi setiap orangnya pada tahun 2013 menjadi 4,8 kali rata-rata transaksi per-orangnya pada tahun 2014. Penurunan pertumbuhan dibawah $20 \%$ juga terjadi pada penjualan total rata-rata merchant di setiap nasabah. Peningkatan terjadi pada biaya pemasaran dari tahun 2012 sampai dengan tahun 2014. Namun, rasio pertumbuhan transaksi dari banyaknya pemegang kartu kredit mengalami penurunan. Oleh sebab itu, menurut Annie dan Kumar (2012) tantangan terbesar perusahaan dalam pengumpulan atau penggalian informasi penting (data mining) pada historical data stream transaksi kartu kredit berdasarkan segmen nasabah diharapkan lebih tepat sasaran dalam menentukan target pasar (Brachman, 1996), menekan biaya pemasaran, meningkatkan penggunaan kartu dan meningkatkan fee based income perusahaan.
Tiga kelompok variabel yang digunakan secara luas dalam melakukan segmentasi pasar konsumen menurut Jaman (2012), yaitu a) segmentasi geografis, yaitu karakteristik nasabah berdasarkan unit-unit geografis; b) segmentasi demografis, menurut Krishnamurthi (2007) dibagi menjadi kelompok-kelompok seperti: pekerjaan, penghasilan, pendidikan dan usia; c) segmentasi psikografis dibagi menjadi kelompok berbeda berdasarkan gaya hidup atau kepribadian dan nilai (Kotler dan Lane, 2008).

Penelitian ini bertujuan menganalisis karakteristik konsumen dalam menggunakan kartu kreditberdasarkan faktor demografis (Garver et al. 2012; Davies et al. 2009) dengan karakteristik pekerjaan, penghasilan, pendidikan, usia, asal wilayah, geografis nasabah dan identifikasi jenis merchant kartu kredit berdasarkan pola transaksi. Data mining dapat diterapkan dalam berbagai data stream yang pada penerapannya akan menjadi dua kategori (Liu et al. 2009), yaitu transactional data stream yang mencatat kegiatan interaksi antara dua entitas dan measurement data stream, mencatat hasil pengukuran sebuah entitas. Data stream terdiri atas data berseri pada waktu tertentu dan memiliki kolom yang berisi data-data berupa transaksi yang telah diidentifikasi memiliki nilai untuk dapat diolah.

Teknik clustering mining dengan k-Means algorithm pada data mining dapat digunakan sebagai solusi untuk analisis segmentasi berdasarkan faktor demografis dan geografis nasabah dalam mengelompokkan jumlah data stream transaksi berukuran besar dengan waktu komputasi yang relatif cepat dan efisien (Alfina et al. 2012). Assocation Rules Mining (ARM) dengan Apriori Algorithm digunakan sebagai identifikasi frekuensi pola merchant yang sering digunakan sebagai tempat bertransaksi. Penelitian dengan menggabungkan hasil clustering dan ARM ini diharapkan dapat membantu dalam pengambilan keputusan manajemen dan dijadikan sebagai rekomendasi strategi menetapkan target nasabah dalam bidang pemasaran sehingga dapat meningkatkan jumlah transaksi kartu kredit.

Merujuk pada penelitian Alfi Wijaya tahun 2006 dengan rumusan alternatif strategi pemasaran sesuai segmentasi pasar, faktor memilih dan preferensi nasabah terhadap bank syariah. Persamaannya membuat rumusan alternatif strategi pemasaran sesuai dengan 
segmentasi pasar, perbedaaannya pada penelitian ini tidak menggunakan teknik data mining clustering dan ARM untuk pengolahan data.

Rujukan penelitian berikutnya oleh Cahyo (2002) bertujuan menganalisis keterkaitan profil demografis dan psikografis dengan pola penggunaan kartu menggunakan analisis cross tabulation dengan alat bantu SPSS dan uji Chi-Kuadrat. Persamaan pada penelitian ini menganalisis konsumen berdasarkan faktor demografis dan pola penggunaan kartu sedangkan perbedaannya pada penggunaan metode data mining dan menggunakan alat bantu software orange mining.

Penelitian lainnya terkait dengan segmentasi pasar pada penelitian Robson et al. (2013) dan penelitian terkait kartu kredit dengan menggunakan teknik data mining oleh Zheng (2009). Perbedaannya adalah variabel yang digunakan dalam identifikasi konsumen menggunakan faktor psikografis dan menggali data nasabah berdasarkan metode-metode pada data mining menggunakan metode decision tree algorithm, neural networks, X-Mean dan Apriori.

Proses pembentukan target pasar kartu kredit menggunakan duateknik data mining dalammenentukan segmentasi nasabah dan identifikasi pola merchant yang sering digunakan. Identifikasi segmentasi nasabah berdasarkan karakteristik pekerjaan, penghasilan, pendidikan, asal wilayah, usia menggunakan teknik clustering didukung dengan reduksi dimensi variabel menggunakan Principal Component Analysis (PCA) dan penilaian Silhoette Coeefisient (SC) yang mendekati nilai 1. Hasil seleksi nasabah berdasarkan random sampling rumus slovin digunakan sebagai preprocessing sebelum dilakukan proses penentuan pola transaksi jenis merchant dengan ARM. Penggabungan dua teknik data mining ini bertujuan dalam memberikan rekomendasi bagi perusahaan menentukan target pasar dan identifikasi keterkaitan pola antar jenis merchant.

\section{METODE PENELITIAN}

Jenis data yang digunakan dalam penelitian ini adalah data sekunder harian berupa data time series yang diambil langsung dari Data Ware House (DWH) transaksi kartu kredit sejak 1 Januari 2010 sampai dengan 31 Desember 2014. Data-data yang digunakan dalam penelitian ini adalah data profile nasabah, data merchant dan historical data transaksi yang telah tercatat pada transaksi kartu kredit. Jumlah data nasabah yang tercatat sebesar 272.067 yang tersebar diseluruh kota di Indonesia berdasarkan karakteristik demografis dan geografis yang terdiri dari nomor nasabah, pekerjaan, penghasilan, pendidikan, umur, kota asal. Data profil nasabah terdiri atas 26 jenis pekerjaan, 7 rentang penghasilan, 7 jenis pendidikan, 6 daftar kisaran usia, dan 34 daftar wilayah. Historical data transaksi yang diperoleh selama 5 tahun berkisar 13.765 .577 data berdasarkan 16 group merchant transaksi. Alat yang digunakan sebagai pengolahan data adalah Orange Mining, dan database SQL Server.

Penelitian menggunakan metode kuantitatif dengan analisis pada data-data numerik. Hal ini, bertujuan mendapatkan gambaran yang jelas terhadap data yang diperoleh. Dengan demikian, dapat menjadi informasi baru yang bisa digunakan terhadap permasalahan yang sedang diteliti.

Penelitian menggunakan gabungan dua teknik data mining dengan teknik clustering dan ARM. ARM dapat digunakan pada market basket transaction (Sim, 2009). ARM mencari hubungan antar item dalam suatu data set yang ditentukan (Han, 2001), meliputi dua tahap menurut Ulmer dan David (2002) yaitu pertama mencari kombinasi yang paling sering terjadi dari suatu itemset atau himpunan dari item-item yang muncul bersama-sama (Kotsiantis dan Kanellopoulos, 2006), kedua adalah mendefinsikan condition dan result untuk conditional association rule. Clustering merupakan proses pengelompokan sekumpulan objek fisik atau abstrak kedalam kelas atau objek yang serupa (Vaishali, 2014; Han \& Kamber, 2006). Cluster dapat disebut juga sebagai koleksi objek data yang memiliki kesamaan satu sama lain dalam kelompok yang sama dan berbeda dengan objek dikelompok lain.

Dalam data mining terdapat permasalahan yaitu salah satunya adalah banyaknya data, sehingga terdapat kemungkinan terjadinya duplikasi data (Tan et al. 2006). Salah satu solusinya adalah menggunakan anti-monotic. Anti-monotic mempunyai tujuan mengurangi masalah kompleksitas komputasi dengan cara mengurangi jumlah kandidat menggunakan teknik pemangkasan, seleksi, mengurangi jumlah perbandingan atau disebut juga pre-processing. Anti-monotic dapat digunakan dalam apriopri principle, dengan nilai support yang tidak pernah melebihi dari minimum support yang telah ditentukan sehingga diasumsikan bahwa item dalam 
setiap transaksi disimpan dan diurutkan dalam urutan leksikografis, hal ini digunakan untuk mengadaptasi algoritma jika terjadi kasus di mana database disimpan secara normalisasi (Srikant, 1996; Gürel, 2008).

Proses pembentukan segmentasi nasabah berdasarkan transaksi pada suatu merchant menggunakan tekhnik clustering k-Means dan ARM dengan apriori, dimana kedua teknik berperan besar sebagai pengolahan data berbasis sistem informasi. Dalam menyeleksi data nasabah dan transaksi dibutuhkan beberapa tahapan pre-processing sebelum menjalankan data mining, yaitu sebagai berikut:

1) Data yang diperoleh dari data nasabah dan DWH Historical transaksi perusahaan dalam bentuk tabel dikumpulkan dan dimasukkan kedalam tabel baru SQL Server 2000. Tabel baru nasabah tersebut terdiri atas dua tabel, yaitu t_nasabah terdiri dari kode nasabah, kode penghasilan, kod epekerjaan, kode pendidikan, kode usia, dan kode wilayah. t transaksi terdiri dari tanggal, kode nasabah, kode kartu, kode merchant

2) Proses seleksi dilakukan dengan pemangkasan data menggunakan fungsi IF dan ELSE untuk mengetahui apakah data-data nasabah tersebut memiliki jumlah transaksi atau tidak. Jika data nasabah tidak memiliki data transaksi maka data nasabah akan dieliminasi sehingga data hanya terdiri dari data yang memiliki transaksi.

Pemangkasan data nasabah dibutuhkan dengan mengeliminasi data pasif atau tidak pernah bertransaksi. Dengan menggunakan kondisi fungsi IF dan ELSE, pemangkasan bertujuan menseleksi data sehingga dari 272.067 akan dipangkas menjadi 95.906 data. Selanjutnya pemangkasan data nasabah kembali dilakukan dengan menggunakan kriteria pengecekan transaksi merchant yang terdaftar dalam group merchant. Setelah itu dilakukan pengecekan valid-nya kriteria nasabah berupa kode pekerjaan, kode penghasilan, kode pendidikan, kode wilayah dan kode usia. Dari hasil pemangkasan data berdasarkan merchant dan kriteria nasabah akan memangkas menjadi 1938 data nasabah.

3) Seleksi dilanjutkan dengan menyeleksi data populasi dengan menggunakan metode random sampling rumus slovin. Pemangkasan data menggunakan random sampling bertujuan mengurangi kompleksitas dan besarnya jumlah data populasi. Populasi penelitian dari 1 Januari 2010 sampai dengan 31 Desember 2014 memiliki profil pekerjaan, penghasilan, pendidikan, usia, wilayah dan berjumlah 1938 data nasabah aktif yang telah bertransaksi pada mesin EDC dalam negeri. Besarnya sampel data nasabah pada penelitian ini berdasarkan rumus Slovin:

$$
\begin{aligned}
\mathrm{n} & =\frac{N}{\left(N(d)^{2}+1\right)} \rightarrow=\frac{1938}{\left(1938(0.05)^{2}+1\right)} \\
& =331,56
\end{aligned}
$$

Keterangan: n (Sampel); N (Populasi); d (Nilai presisi $95 \%$ atau sigma $=0,05$ (tingkat kesalahan yang dikehendaki adalah 5\%))

Senjutnya, random sampling dilakukan dengan cara mengurutkan data dari nilai terbesar sampai dengan yang terkecil sebanyak 350 data nasabah. Preprocessing juga berfungsi dalam mengkonversi data sehingga bisa diolah pada proses klasterisasi k-Means dan proses ARM. Pertama adalah pengubahan data variabel pekerjaan, penghasilan, pendidikan, umur dan wilayah dengan pengkodean ordinal atau skala. Data merchant di groupkan menjadi sebuah kode group merchant dengan mengubah nilai return menjadi " $1=$ transaksi dan "?" = tidak bertransaksi. Tabel hasil konversi variabel menjadi pengkodean skala dapat dilihat pada Tabel 1.

Pre-processing data menggunakan Principal Componen Analysis (PCA) bertujuan menyederhanakan variabel yang diamati dengan cara menyusutkan/ mereduksi dimensi variabel (Helbich et al. 2013) dengan menghilangkan korelasi diantara variabel bebas melalui transformasi variabel bebas asal ke variabel baru yang tidak berkorelasi sama sekali. PCA memproyeksikan citra kedalam subspace dalam menentukan sistem koordinat baru dari dataset nasabah. Reduksi data menggunakan PCA dapat mengurangi dimensi dan menyederhanakan informasi. Konversi hasil reduksi menjadi PC1, PC2 dapat dilihat pada Tabel 2.

\section{HASIL}

\section{Segmentasi Nasabah dengan Clustering K-Means}

Pembentukan segmentasi nasabah berdasarkan pengolahan data pre-processing menghasilkan 350 data nasabah dan variabel yang lebih sederhana PC1 dan PC2. Clustering k-Means dengan menggunakan 
alat bantu software orange tools membutuhkan pengaturan identifikasi awal jumlah cluster yang akan dibentuk mulai dari 2 sampai dengan 8 cluster dan pengaturan maksimal iterasi (penghitungan jarak antar antar item) yang akan dijalankan maksimal sebanyak 10 perulangan. Proses iterasi dilakukan secara berulang sampai tidak adanya perubahan atau perpindahan item pada cluster yang terbentuk. Hasil dari silhouette terbaik menunjukkan nilai yang paling mendekati nilai 1. Selama 10 kali percobaan menghasilkan $\mathrm{k}=3$ dan rentang score yang didapatkan adalah 0,39 dan 0,40 .

Hasil score k-Means dan scatter plot menghasilkan score yang tertinggi adalah $\mathrm{k}=3$ yang berarti cluster berdasarkan silhouette coefficient terbaik adalah 3 dengan score $=0,40$, atau paling mendekati 1 . Namun, terdapat kekurangan pada penggunaan alat bantu software orange, yaitu tidak diketahuinya variable acak cluster yang dipilih pertama kali sebagai candidate awal cluster dan tidak ditampilkannya berapa banyak iterasi yang telah dilakukan untuk mendapatkan masing-masing nilai k terbaik tersebut. Kelebihannya berdasarkan 10 kali percobaan, hasil cluster tetap stabil berdasarkan hasil silhouette yang memiliki rentang tidak terlalu berbeda antara 0,39 sampai dengan 0,40. Hasil dari pembentukan scatter plot dan percobaan k-Means dapat dilihat pada Gambar 1.

Tabel 1. Tabel Konversi variabel pekerjaan, penghasilan, pendidikan, usia, wilayah dan merchant

\begin{tabular}{|c|c|c|c|c|c|}
\hline Variabel & Kode & Variabel & Kode & Variabel & Kode \\
\hline Nama Wilayah & & Sumatera Barat & 13 & Polisi & 22 \\
\hline Aceh & 11 & Sumatera Selatan & 16 & Paramedis & 23 \\
\hline Bali & 51 & Sumatera Utara & 12 & Petani/Nelayan & 24 \\
\hline Banten & 36 & Surabaya & 37 & Wartawan & 25 \\
\hline Bengkulu & 17 & Ujung Pandang & 73 & Pegawai Yayasan & 26 \\
\hline Dki Jakarta & 31 & Yogyakarta & 34 & Penghasilan & \\
\hline Jambi & 15 & Pekerjaan & & $<1$ juta & 1 \\
\hline Jawa Barat & 32 & Pegawai Negeri/PNS & 1 & $1-5 \mathrm{jt}$ & 2 \\
\hline Jawa Timur & 35 & TNI/ABRI/Militer & 2 & $5-10 \mathrm{jt}$ & 3 \\
\hline Jawatengah & 33 & Pegawai Swasta/Karyawan- & 3 & $10-25 \mathrm{jt}$ & 4 \\
\hline Kalimantan Barat & 61 & Swasta & & $25-50 \mathrm{jt}$ & 5 \\
\hline Kalimantan Selatan & 63 & Profesional & 4 & $50-100 \mathrm{jt}$ & 6 \\
\hline Kalimantan Tengah & 62 & Wiraswasta/Wirausaha & 5 & $>100 \mathrm{jt}$ & 7 \\
\hline Kalimantan Timur & 64 & Pensiun/Pensiunan & 6 & Pendidikan & \\
\hline Kalimantan Utara & 65 & Akuntan & 7 & $\mathrm{SD}$ & 1 \\
\hline Kep Bangka Belitung & 19 & Dokter & 8 & SMP & 2 \\
\hline Kep Riau & 14 & Engineer/Teknisi & 9 & SMA & 3 \\
\hline Lampung & 18 & Guru/Dosen & 10 & D3 & 4 \\
\hline Maluku & 81 & Ibu Rumah Tangga & 11 & $\mathrm{~S} 1$ & 5 \\
\hline Nusa Tenggara Barat & 52 & Konsultan & 12 & $\mathrm{~S} 2$ & 6 \\
\hline Nusa Tenggara Timur & 53 & Pegawai Koperasi & 13 & S3 & 7 \\
\hline Palembang & 14 & Mahasiswa/Pelajar & 14 & Usia & \\
\hline Papua & 92 & Notaris & 15 & Dibawah $<18$ Tahun & 1 \\
\hline Riau & 14 & Pegawai BUMN/BUMD & 16 & 18-24 Tahun & 2 \\
\hline Sulawesi Barat & 76 & Pengacara & 17 & 25-29 Tahun & 3 \\
\hline Sulawesi Selatan & 73 & Pekerja Informal & 18 & 30-39 Tahun & 4 \\
\hline Sulawesi Tengah & 72 & Pekerja Seni & 19 & 40-55 Tahun & 5 \\
\hline Sulawesi Tenggara & 74 & Pekerja Sosial/Lsm & 20 & $>55$ Tahun & 6 \\
\hline Sulawesi Utara & 71 & Pejabat Negara & 21 & & \\
\hline
\end{tabular}


Pola Merchant dengan Association Rule Mining (ARM)

Identifikasi pola jenis merchant kartu kredit yang diteliti harus berdasarkan aturan minimum support dan minimum confidence. Minimum support digunakan untuk menguji pembentukan hasil data yang diperoleh berdasarkan $1 \%, 5 \%, 20 \%, 40 \%$ dan $50 \%$ sehingga dapat menjadikannya sebagai aturan dalam penentuan minimum support frequently itemsets (Tabel 3).
Hasilnya menunjukkan jumlah data yang semakin besar tidak mendukung semakin besarnya minimum support kemunculan merchant. Semakin besarjumlah data maka akan semakin kecil nilai minimum support yang akan dihasilkan (Tan et al. 2006). Pada minimum support diatas 20\% menghasilkan hanya 1 jenis merchant saja yang dominan dan sering digunakan. Oleh karena itu, frekuensi digunakannya merchant setiap tahunnya lebih menunjukkan hubungan antar merchant menggunakan minimum support $1 \%$.

Tabel 2. Tabel konversi hasil reduksi PCA data nasabah

\begin{tabular}{rcccccrc}
\hline \multicolumn{1}{c}{ Nasabah } & Pekerjaan & Penghasilan & Pendidikan & Wilayah & Usia & \multicolumn{1}{c}{ PC1 } & PC2 \\
\hline 9989042 & 1 & 2 & 5 & 31 & 6 & 0.3197 & 0.830032 \\
914111000 & 1 & 3 & 7 & 31 & 6 & 0.640042 & 2.231384 \\
225140000 & 1 & 3 & 3 & 33 & 5 & -0.11337 & -0.88818 \\
509557001 & 1 & 3 & 5 & 35 & 4 & 1.294559 & -0.34784 \\
28392011 & 1 & 4 & 5 & 35 & 6 & -0.5743 & 1.056101 \\
76868008 & 1 & 2 & 3 & 73 & 5 & -0.6512 & -2.43649 \\
869263000 & 1 & 3 & 5 & 31 & 6 & -0.0804 & 1.011413 \\
6955010 & 1 & 2 & 4 & 63 & 5 & -0.05649 & -1.48477 \\
7179037 & 1 & 6 & 3 & 52 & 5 & -1.7592 & -0.99333 \\
22011022 & 1 & 2 & 5 & 14 & 4 & 2.187078 & 0.188419 \\
1410495001 & 1 & 3 & 5 & 35 & 5 & 0.560181 & 0.263442 \\
7090037 & 1 & 6 & 3 & 52 & 5 & -1.7592 & -0.99333 \\
1706043 & 1 & 6 & 5 & 31 & 5 & -0.54634 & 0.944278 \\
1197168001 & 1 & 3 & 5 & 31 & 5 & 0.653974 & 0.400135 \\
3211037 & 1 & 5 & 5 & 52 & 4 & 0.095729 & -0.56602 \\
\hline
\end{tabular}

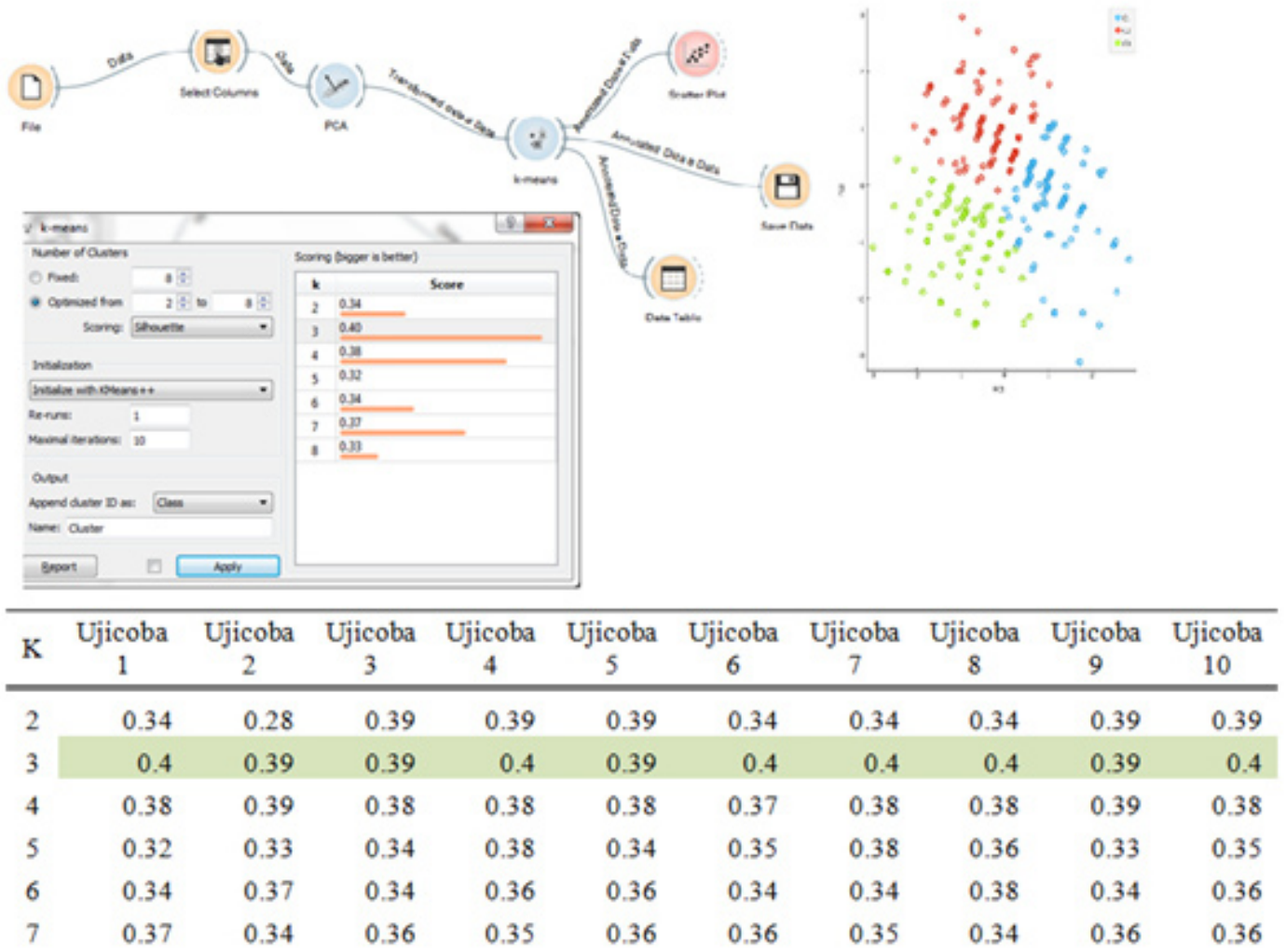

Gambar 1. Hasil percobaan k-Means menggunakan tools orange 
Penelitian ini menggunakan pengujian dengan nilai minimum confidence sebesar $40 \%$ yang didapatkan berdasarkan asumsi tiga segmentasi konsumen melalui clustering k-Means (Tabel 4). Apabila tiga segmentasi berdasarkan karakteristik konsumen maka memberikan kesempatan sebesar 33,33\% dan dibulatkan menjadi $40 \%$ terhadap kemungkinan terjadinya transaksi kartu kredit pada keseluruhan nasabah yang diteliti. Oleh karena itu penelitian ini dapat di tetapkan minimum confidence ARM sebesar 40\%, berdasarkan tiga segmentasi nasabah yang terbentuk.

Hasil identifikasi role menggambarkan keterkaitan antar merchant yang memenuhi kriteria minimum support $1 \%$ dan minimum confidence $40 \%$ adalah sebanyak 2 role, yaitu (1) HHL $\rightarrow$ RRT. Artinya, jika (antecedent) merchant HHL ditransaksikan maka (consequent) merchant RRT akan ikut ditransaksikan yang memiliki nilai kepercayaan sebesar 54\% dan didukung oleh 1\% dari seluruh data yang merupakan kombinasi keduanya. (2) RSS $\rightarrow$ RRT. Artinya, jika (antecedent) merchant RSS ditransaksikan maka (consequent) merchant RRT akan ikut ditransaksikan yang memiliki nilai kepercayaan sebesar $60 \%$ dan didukung oleh $1 \%$ dari seluruh data yang merupakan kombinasi keduanya. Dari hasil pengujian juga menunjukkan 37 role tingkat confidence $100 \%, 75 \%$ dan $50 \%$ pada suatu merchant namun hanya memiliki tingkat kepercayaan rentang $0,1-1 \%$. Sehingga dapat disimpulkan role terbaik yang yang diambil adalah 2 role dengan menghasilkan 2 itemset diatas minimum support $1 \%$ dan minimum confidence sebesar $40 \%$

\section{Pembentukan Target Pasar berdasarkan Segmentasi Nasabah (Clustering) dan Pola Merchant (ARM)}

Hasil dari segmentasi nasabah yang telah diolah menggunakan teknik Clustering dan identifikasi frekuensi pola merchant yang terbentuk menggunakan teknik ARM menjadikannya sebagai target pasar berdasarkan pengelompokkan segmen nasabah potensial terhadap kecenderungan jenis merchant kartu kredit yang akan digunakan. Hasil ini ditujukan sebagai kebutuhan pengembangan kegiatan promosi dan target pemasaran.

Hubungan pada pola merchant pertama dan 3 segmen nasabah menghasilkan jenis merchant hotel (HHL) dan restaurant (RRT) memberikan informasi bahwa cluster pertama memiliki kriteria pekerjaan PNS, penghasilan Rp10-25 juta, pendidikan SMA, umur 40-55 tahun dan asal Sulawesi Selatan. Pada cluster kedua memiliki segmen pekerjaan PNS, penghasilan Rp25-50 juta, pendidikan S1, umur 40-55 tahun, asal DKI Jakarta, Jawa Tengah dan Banten. Pada cluster ketiga memiliki karakteristik pekerjaan PNS, berpenghasilan Rp5-10 juta, pendidikan S1, umur 30-39 tahun dan asal dari Riau, Jawa Barat, Jawa Tengah, Banten.

Tabel 3. Hasil data uji minimum support dari frequently itemset

\begin{tabular}{|c|c|c|c|c|c|c|}
\hline Tahun & Jumlah & Min Sup > 1\% & Min Sup $>5 \%$ & Min Sup $>20 \%$ & Min Sup $>40 \%$ & Min Sup $>50 \%$ \\
\hline 2010 & 48 & $\begin{array}{l}3 \text { merchant } \\
\text { (tel,rrt,rbs) }\end{array}$ & 1 merchant (rrt) & 1 merchant (rrt) & 1 merchant (rrt) & 0 merchant \\
\hline 2011 & 74 & $\begin{array}{l}4 \text { merchant } \\
\text { (tel,rss,rfc,rrt) }\end{array}$ & 1 merchant (rrt) & 1 merchant (rrt) & 1 merchant (rrt) & 1 merchant (rrt) \\
\hline 2012 & 140 & 1 merchant (rrt) & 1 merchant (rrt) & 1 merchant (rrt) & 1 merchant (rrt) & 1 merchant (rrt) \\
\hline 2013 & 266 & $\begin{array}{l}2 \text { merchant } \\
\text { (cdm,rrt) }\end{array}$ & 1 merchantser (rrt) & 1 merchant (rrt) & 1 merchant (rrt) & 1 merchant (rrt) \\
\hline 2014 & 177 & $\begin{array}{l}8 \text { merchant } \\
\text { (tel,rss,hhl,rrt, ros, } \\
\text { rps,rbs,roe }\end{array}$ & $\begin{array}{l}3 \text { merchant } \\
\text { (rtt,rss,hhl) }\end{array}$ & 1 merchant(rrt) & 1 merchant (rrt) & 1 merchant (rrt) \\
\hline ALL & 705 & $\begin{array}{l}4 \text { merchant }(\mathrm{hhl}, \\
\text { tel, rrt, rss) }\end{array}$ & 1 merchant(rrt) & 1 merchant(rrt) & 1 merchant (rrt) & 1 merchant (rrt) \\
\hline
\end{tabular}


Sementara itu, hubungan pada pola merchant kedua dan pada 3 segmen nasbaah menghasilkan jenis merchant service station (RSS) dan restaurant (RRT) memberikan informasi bahwa cluster pertama berpenghasilan pekerjaan PNS, Rp1-25 juta, pendidikan SMA umur 40-55 tahun dan asal Sulawesi selatan. Pada cluster kedua berpenghasilan pekerjaan PNS, diatas Rp10 50 juta, pendidikan S1-S2, umur 40-55 tahun dan asal DKI Jakarta. Pada cluster ketiga pekerjaan PNS, berpenghasilan Rp1-5 juta, pendidikan SMA \& S1, umur 25-29 tahun asal Riau, Jawa Barat, Palembang, DKI Jakarta, Yogyakarta.

Tabel 4 . Hasil minimum support $0,1 \%$ dan minimum confidence $40 \%$

\begin{tabular}{|c|c|c|c|c|c|}
\hline Itemset & Antecedent & Consequent & Minimum Support $(\%)$ & Minimum Confidense (\%) & Count \\
\hline 2 & HHL & RRT & 1 & 54 & 14 \\
\hline 2 & RSS & RRT & 1 & 60 & 9 \\
\hline 4 & RPS,RBS, ROE & RRT & 0,1 & 100 & 1 \\
\hline 4 & RRT,HHL, RBS & RSS & 0,1 & 100 & 1 \\
\hline 4 & RRT, RBS, ROE & RPS & 0,1 & 100 & 1 \\
\hline 4 & RRT,RPS, RBS & ROE & 0,1 & 100 & 1 \\
\hline 4 & RRT, RPS, ROE & RBS & 0,1 & 100 & 1 \\
\hline 4 & RSS, HHL, RBS & RRT & 0,1 & 100 & 1 \\
\hline 4 & RSS, RRT, HHL & RBS & 0,1 & 100 & 1 \\
\hline 4 & RSS, RRT,RBS & HHL & 0,1 & 100 & 1 \\
\hline 3 & HHL,RBS & RSS & 0,1 & 100 & 1 \\
\hline 3 & HHL, RBS & RRT & 0,1 & 100 & 1 \\
\hline 3 & RBS,ROE & RPS & 0,1 & 100 & 1 \\
\hline 3 & RBS,ROE & RRT & 0,1 & 100 & 1 \\
\hline 3 & RPS,RBS & RRT & 0,1 & 100 & 1 \\
\hline 3 & RPS,RBS & ROE & 0,1 & 100 & 1 \\
\hline 3 & RPS,ROE & RBS & 0,1 & 100 & 1 \\
\hline 3 & RPS,ROE & RRT & 0,1 & 100 & 1 \\
\hline 3 & RRT,ROE & RPS & 0,1 & 100 & 1 \\
\hline 3 & RRT,ROE & RBS & 0,1 & 100 & 1 \\
\hline 3 & RSS,HHL & RRT & 0,1 & 100 & 1 \\
\hline 3 & RSS,HHL & RBS & 0,1 & 100 & 1 \\
\hline 3 & RSS,RBS & HHL & 0,1 & 100 & 1 \\
\hline 3 & RSS,RBS & RRT & 0,1 & 100 & 1 \\
\hline 3 & TEL,HHL & RRT & 0,1 & 100 & 1 \\
\hline 3 & TEL,RBS & RRT & 0,1 & 100 & 1 \\
\hline 2 & HHL,RBS & RSS,RRT & 0,1 & 100 & 1 \\
\hline 2 & RBS,ROE & RRT,RPS & 0,1 & 100 & 1 \\
\hline 2 & RPS,RBS & RRT,ROE & 0,1 & 100 & 1 \\
\hline 2 & RPS,ROE & RRT,RBS & 0,1 & 100 & 1 \\
\hline 2 & RRT,ROE & RPS,RBS & 0,1 & 100 & 1 \\
\hline 2 & RSS,HHL & RRT,RBS & 0,1 & 100 & 1 \\
\hline 2 & RSS,RBS & RRT,HHL & 0,1 & 100 & 1 \\
\hline 2 & RBS & RRT & 0,1 & 50 & 3 \\
\hline 2 & $\mathrm{RCP}$ & RRT & 0,1 & 50 & 1 \\
\hline 2 & RFC & TEL & 0,1 & 50 & 1 \\
\hline 2 & RFC & RHA & 0,1 & 50 & 1 \\
\hline 2 & RHA & RFC & 0,1 & 50 & 1 \\
\hline 2 & RPS & RRT & 0,1 & 75 & 3 \\
\hline
\end{tabular}




\section{Implikasi Manajerial}

Hasil penelitian pembentukan target pasar kartu kredit berdasarkan data stream transaksi kartu kredit di PT Bank Bukopin dibutuhkan beberapa hal yang menjadi prioritas manajemen dalam menetapkan strategi peningkatan transaksi kartu kredit, yaitu (1) meningkatkan kerjasama bisnis pada jenis merchant hotel, service station, dan restaurant; (2) meningkatkan kegiatan promosi dengan menghubungkan diskon atau cashback pada jenis merchant hotel-restaurant dan merchant service station-restaurant agar tepat sasaran dan dapat mengefisiensikan biaya promosi; (3) identifikasi perubahan segmen nasabah dan pola persebaran transaksi pada merchant secara periodik tahunan; (4) penggunaan database Data Warehouse transaksi kartu kredit dapat terus digali manfaatnya dengan teknik data mining dalam meningkatkan efektivitas perencaaan promosi kartu kredit.

\section{KESIMPULAN DAN SARAN}

\section{Kesimpulan}

Penggunaan Simple Random Sampling dengan rumus Slovin dan PCA berguna dalam menyederhanakan populasi dan mereduksi variabel yang digunakan pada awal proses pengolahan data dengan menggunakan data mining. Hasil penelitian menggunakan cluster mining menghasilkan tiga cluster segmentasi atau $\mathrm{k}=3$ terbaik berdasarkan 5 karakteristik nasabah, yaitu pekerjaan, pendidikan, penghasilan, usia dan asal wilayah nasabah. Hasil nilai silhouette coeffisien yang dihasilkan dalam 10 kali percobaan memiliki rentang $0,39-0,40$ atau paling mendekati nilai satu, artinya hasil dominan dari percobaan dapat dipilih sebagai tiga cluster segmentasi terbaik. Penggunaan ARM untuk mendapatkan pola transaksi pada merchant berdasarkan nilai minimum support $1 \%$ dan minimum confidence $40 \%$ menghasilkan dua pola jenis merchant. Pola pertama jika hotel (HHL) ditransaksikan maka restaurant (RRT) akan ikut ditransaksikan. Pola kedua jika bertransasi pada service station (RSS) maka restaurant (RRT) akan ikut serta ditransaksikan. Dari hasil penelitian dapat disimpulkan merchant jenis restaurant memiliki frekuensi tersering digunakan oleh nasabah pemegang kartu kredit. Pembentukan target pasar pada penelitian ini menghasilkan 3 kelompok konsumen pada 2 pola jenis merchant yang sering ditransaksikan oleh nasabah berdasarkan pekerjaan, penghasilan, pendidikan usia dan asal wilayah.

Penelitian juga menyimpulkan bahwa penggunaan data mining dengan Clustering dan ARM dapat bermanfaat dalam pembentukan segmentasi berdasarkan karakteristik nasabah dan identifikasi pola jenis merchant yang sering digunakan dalam menetapkan target pasar kartu kredit.

\section{Saran}

Saran yang dapat diberikan pada penelitian ini yaitu perlunya analisis terhadap persebaran transaksi selain transaksi (on us) atau transaksi yang dilakukan tanpa menggunakan kartu kredit penerbit atau EDC (Electronic Data Capture) penerbit sehingga tidak ditemukan lost data saat dilakukan pengolahan dengan data mining. Perlunya identifikasi segmen pada faktorfaktor demografi lainnya dan psikografis nasabah seperti: jenis kelamin, tempat tinggal domisili, perilaku, dan ketertarikan konsumen pada jenis merchant. Identifikasi terhadap keluhan konsumen pada call center kartu kredit dapat dijadikan faktor menarik dalam menggali informasi merchant dan kepuasan konsumen kartu kredit. Kegiatan promosi seperti potongan harga (diskon) menghubungkan jenis merchant restaurant dengan jenis merchant lainnya, cashback, loyalty program, blasting sms/email, penggunaan billboard, banner dapat diefektifkan secara berkala pada target segmen nasabah yang potensial.

Evaluasi tindak lanjut hasil penelitian ini sebaiknya dilakukan secara berkala atau tahunan agar dapat mengetahui perkembangan upaya peningkatan transaksi kartu kredit terhadap nasabah dan kerja sama business to business dengan merchant. Jumlah sampling nasabah pada penelitian ini terbatas sebesar error 5\% dikarenakan tools yang digunakan maksimal 10.000 data. Oleh karena itu, perlu penelitian lebih lanjut untuk mengetahui pembentukan pasar kartu kredit dengan mengidentifikasi segmentasi konsumen dan pola merchant kartu kredit dengan menggunakan teknik data mining lainnya serta menggunakan alat bantu software lainnya. 


\section{DAFTAR PUSTAKA}

Alfina T, Santosa B, Barakbah A. 2012. Analisis perbandingan metode hierarChical clustering, K-Means dan gabungan keduanya dalam cluster data (studi kasus: problem kerja praktek Jurusan Teknik Industri ITS). Jurnal Teknik ITS 1:521525.

Annie CL, Kumar A. 2012. Market basket analysis for a supermarket based on frequent itemset mining. International Journal of Computer Science 9(3): 257-264.

Bayer J. 2010. Customer segmentation in the telecommunications industry. Journal of Database Marketing \& Customer Strategy Management 17(13): 247-256. https://doi. org/10.1057/dbm.2010.21.

Brachman RJ, Khabasa T, Kloesgen W, Piatetsky Shapiro G, Simoudis E. 1996. Mining bussiness databases. Communications of the ACM 39(11):42-45. https://doi. org/10.1145/240455.240468.

Cahyo A. 2002. Identifikasi segmentasi dan analisis perilaku penggunaan kartu kredit citibank, Bank "X" dan BCA [tesis]. Bogor: Management Business IPB.

Davies CG, Blayney DP, Yen ST, Cooper J. 2009. An analysis of at home demand for ice cream in the united states. Journal of Dairy Science 92(12):6210-6216.https://doi.org/10.3168/ jds.2009-2536.

Garver MS, Spralls SA, Divine RL. 2012 Need based segmentation analysis of university career services: implication for increasing student participation. Research In Higher Education Journal 11(11): 611-628.

Gürel G. 2008. Mining XML documents with association rule algorithms [thesis]. Izmir: Izmir Institute of Technology.

Helbich M, Brunauer W, HAgebauuer J, Leitner M 2013. Data-driven regionalization of housing markets. Annals of the Association of American Geographers 104(3): 460-484.
Jaman M. 2012. Critical analysis of segmentation strategy for potential product launch - mapping the customers. International Journal of Scientific \& Technology Research 1(11):62-65.

Kotler, Amstrong. 2008. Prinsip-prinsip Pemasaran. Ed ke 12. Jakarta: Erlangga.

Kotler P, Lane K. 2008 . Manajemen Pemasaran. Ed ke 12. Jakarta: PT. Macanan Jaya Cemerlang.

Kotsiantis S, Kanellopoulos D. 2006. Association rules mining: a recent overview. GESTS International Transactions on Computer Science and Engineering 32(1):71-82.

Krishnamurthi M. 2007. Improving credit card operations with data mining techniques. Journal of International Technology and Information Management 16(2):43-60.

Liu H, Lin Y, Han J. 2009. Methods for mining frequent items in data streams: an overview. Knowledge Information System 26: 1-30. https://doi. org/10.1007/s10115-009-0267-2.

Mabrur GA, Lubis R. 2012. Penerapan data mining untuk memprediksi kriteria nasabah kredit. Jurnal Komputer dan Informatika (KOMPUTA) 1(1):53-57.

Robson K, Pitt L, Wallstrom A. 2013. Creative market segmentation: understanding the bugs in consumer behavior. Journal of Public Affairs 13(2):218-223. https://doi.org/10.1002/pa.1477.

Sim THA. 2009. Discovering of association rules without a minimum support threshold - coherent rules discovery [dissertation]. Victoria: Monash University Australia.

Srikant R. 1996. Fast algorithms for mining association rules and sequential patterns [dissertation]. Wisconsin: University of Wisconsin.

Tan PN, Steinbach M, Kumar V. 2006. Introduction to Data Mining. Ed ke-1. Boston: Pearson.

Vaishali. 2014. Fraud detection in credit card by clustering approach. International Journal of Computer Applications 98(3):29-32.https://doi. org/10.5120/17164-7225.

Zheng Y. 2009. Analysis of credit card data based on data mining technique [thesis]. Ottawa: Quebec University. 